\title{
Mennyiben pontosíthatja a georadaros vizsgálat a homokterületek geomorfológiai kutatásának eredményeit? Komplex tanulmány egy belső-somogyi homokbuckán
}

\author{
GYÖRGYÖVICS KATALIN és KATONA ORSOLYA
}

\author{
H-7461 Kaposvár, Váci Mihály utca 40., \\ e-mail: katalingy87@gmail.com, katonaorsolyag@gmail.com
}

\begin{abstract}
GYÖRGYÖVICS, K. \& KATONA, O.: Can georadar surveying contribute to clarifying aeolian research results? Complex study on a sand dune in Inner Somogy, Hungary.

Abstract: A complex geomorphological research was carried out on an aeolian sand dune in Inner Somogy, Hungary. Sedimentological analysis showed three layers of sediment composed of sand with differing characteristics (Györgyövics et al., 2014) which suggested at least 3 aeolian phases in the region. OSL dating of samples from the same boreholes confirmed these periods and determined that sand was deposited during the Late Glacial, the Dryases and Boreal phase (Kiss et al. 2012). However, carrying out a GPR survey revealed much more detailed structure of the particular dune. Comparing research results and applying GPR profiling in the early stages of geomorphological investigation could help choosing the OSL sampling points and depths resulting in a more precise study.
\end{abstract}

Keywords: GPR, stratigraphy, aeolian sediments, landscape development

\section{Bevezetés}

A homokterületek vizsgálatával a mérsékelt övben, így a Kárpát-medencében is jól kimutatható az éghajlat változása akár több tízezer évre visszamenőleg is. Az üledék kötetlen jellegéből, vagyis a homok tulajdonságaiból adódik, hogy a klíma legtöbb elemének változásaira rendkívül érzékeny: meleg, csapadékszegény időszakban könnyen átalakul a felszín, hüvös, de csapadékosabb periódusokban kisebb változások, módosulások történnek, míg nedves, csapadékos éghajlaton stabilizálódnak az eolikus formák és más folyamatok, mint a felszíni leöblítés és a mocsarakban történő finom por ülepedése válnak jellemzővé. A másmás klimatikus szakaszokban mutatott, jól leírható változás teszi ideális klimatikus kutatási területté ezeket a vidékeket. Azonban mivel a felszín átalakulása különböző mértékű az eltérő klímájú periódusokban, és gyakran az emberi tevékenység is kisebb-nagyobb módosításokat indukál, a változások utólagos rekonstrukciójához, a teljes felszínfejlődés részletes megismeréséhez interdiszciplinális kutatásra, vagyis több módszer együttes használatára van szükség.

A Dunántúl délnyugati részén fekvő Belső-Somogyot 5-12 méter vastag futóhomok borítja (MAROsı 1970), melynek vizsgálatával megismerhető hazánk legcsapadékosabb homokterületének fejlődéstörténete. A kistájon a pannon rétegekből álló alapra az ŐsDuna épített hordalékkúpot (ÁdÁM et al. 1981), melynek anyagát a szél átdolgozta a würm során (PÉcsı 1962, MARosı 1970, LóKI 1981). Azonban az újabb
OSL mérések alapján (Kıss et al. 2012) az eolikus aktivitás fő időszaka a késő glaciális Dryas időszakaiban volt, majd a homok újra mozgásba lendült a preboreálisban, a boreálisban és antropogén hatásra a szubboreálisban, majd a 17-18. században is.

A terület eolikus formakincséről a 20. század elején Cholnoky (é.n.) írt először, aki a teljes kistájat egy szélbarázda-garmada együttesnek vélte. Később Marosi (1967, 1970) térképezte fel részletesen a szélbarázdamaradékgerinc-garmada formacsoportokat és megállapította, hogy a formák egymásra települve is elöfordulnak. Lóki (1981) készítette el az egész kistájat bemutató 1:100 000 méretarányú geomorfológiai térképet, melyen komplex dűnerendszereket, hosszanti formákat és széllyukakat is ábrázolt. A legújabb kutatások alapján (GYÖRGYÖVIcs és KISS 2013) különböző kitöltöttségű, nagy és közepes parabolabuckák, garmadák és hosszúkás szármaradványok különíthetők el a mintaterületen. Ezek a formák vagy magányosan, egyszerü buckákként fordulnak elő, vagy akár három hierarchia szintben egymásra települhetnek.

Jelen tanulmányunkban Kelet-Belső-Somogy déli részén, a Barcsi Borókásban található közepes parabolabuckák (1. ábra) korábbi szedimentológiai (GYÖRGYÖVICs et al. 2014) és OSL kormeghatározással kapott (Kiss et al. 2012) eredményeit egészítjük ki geofizikai módszerrel kapottakkal. A georadar-GPR (Ground Penetrating Radar) segítségével a korábbi mintavételi helyek (1. ábra, D2 és D3 fúráshelyek) felett, illetve ezekhez igazodva rácshálóban készítettünk felvételeket. A hat kereszt (K-Ny) és egy hosszanti (É-D) irányú szelvények (1. ábra) segítségével megállapítható a homokbucka belső szerkezete, az eolikus szállítás, a forma mozgása során kialakult rétegek kimutathatók, így a pontszerü szedimentológiai és kor adatok kiterjeszthetőek, a kisebb, lokális változások pedig feltárhatók.

\section{Anyag és módszer}

\section{Georadar - Ground Penetrating Radar}

A georadar, egy igen elterjedt sekély mélységü geofizikai módszer, a földtudományok minden ágában. Maga a mérőműszer 3 fő egységből áll; jeladó-, vevőés vezérlőegység (2. ábra). A jeladó egység rövid, magas frekvenciájú elektromágneses (EM) impulzusokat bocsát ki melyek a kibocsátott hullám természetének megfelelően visszaverődnek, megtörnek, szóródnak, miközben interferencia, szuperpozíció, diszperzió, stb. 




1. ábra. A vizsgálati terület elhelyezkedése

lép fel (2. ábra) (JoL, 2009; CASA et al. 2000). Amikor az EM hullám két eltérő elektromágneses tulajdonsággal rendelkező közeg határára ér, akkor egy része visszaverődik, másik része a közegek határán megtörik és belép az új közegbe. A visszaverődés, azaz reflexió sík felület esetén irányított, egyenlőtlen felületen pedig szórt. A reflektált jel nagysága függ a két közeg elektromos permittivitásától és mágneses permeabilitásától. A felszínre visszaérkező módosult hullám információt hordoz az őt ért hatásokról, melyet a vevőegység regisztrál és digitális formában rögzítésre kerül. A georadar tipikusan néhány $\mathrm{MHz}$ - néhány $\mathrm{GHz}$ frekvencia tartományban sugározza ki az EM impulzusokat, ennek megfelelően a behatolási mélység valamint a felbontás minősége a használt EM hullám frekvenciájától függ. Nagyobb frekvencia mellett kisebb behatolási mélységet, de nagyobb felbontást, míg kisebb frekvencia mellett nagyobb behatolási mélységet, de kisebb felbontást kapunk.

A szelvények helyzetének meghatározása során fontos volt figyelembe venni a korábbi mintavételi pontok helyét és a felszín borítottságát. Mivel a zárt, sürü vegetációval borított területek pontatlanná teszik a mérést, ezért távolság-alapú méréseket végeztünk, melyek nyomvonala GPS-el rögzítve volt. Az optimális behatolási mélység és felbontás érdekében a mérésekhez 200 MHz-es antennát használtunk, mely behatolási mélysége a vizsgált közegben 5-6 m volt az adott körülmények között, a felbontása pedig $0,1-0,3 \mathrm{~m}$.
A felvett szelvények kiértékelése RADAN-GSSI programba történt. Az adat feldolgozás során először is a Surface normalization funkció használatával, korrigáltuk a visszaérkezett jelet, vagyis levágásra került a direkt hullám. A következő lépésben a helyreállításra került a regisztrált hullám jel erőssége (gain normalization), vagyis a később - a mélyebben fekvő közegből érkező jeleket erősítettük fel, hiszen azok csillapodása nagyobb.

Az így kapott még nyers adatok esetében eltávolításra kerültek a háttérzajok (Remove Global Background funkcióval), ez a legtöbb csatornán regisztrált koherens jelek - szürésével történt. A következő lépésben alkalmaztuk a FIR (Finite impulse response) sávfiltert - mely a használt antenna frekvenciájának megfelelő jeleket hagy meg (a névleges frekvencia 3-5-ét és 1/3-1/5-ét vagyis a sávfilteren áteresztett frekvenciatartomány 50-600 MHz), s az így kapott szelvények megfelelőek voltak a kvalitatív elemzésre.

\section{Lézer szemcse-összetétel vizsgálat}

A szemcseösszetételt meghatározó lézeres módszer igen elterjedt az utolsó évtizedben, gyorsasága, pontossága, valamint a mérés megismételhetősége miatt (KUN et al. 2013). A módszer alapja, hogy a mintát tartalmazó, vizsgált közegen lézersugarat bocsátunk át, melynek szóródása jellegzetes diffrakciós gyűrűket alkot az érzékelőn. E gyürük elhelyezkedése, mérete és egymástól való távolsága alapján meghatározható a szemcseméret-eloszlás. A mérés során a két leginkább használt elmélet alkalmazható, ezek a Mie és Fraunhofer.

A Fraunhofer elmélet a Mie elmélet egyik változata, de alkalmazásához nem szükségesek a minta optikai paraméterei. Segítségével megmérhető minden részecske, mely mérete kisebb, mint a lézerfény hullámhossza. (LoIzEAU et al., 1994). Hiányossága, hogy a meghatározásra kerülő szemcseméret pontatlanságot mutat ha az átmérője kisebb mint a használt fény hullámhosszának tízszerese (d<10I) (LoIzEAU et al. 1994, Xu and Dı GUIDA 2003) Ezért az agyagfrakció meghatározása ezzel a módszerrel problémás lehet (DI STEFANO et al 2010, Kun et al 2013). Ugyanúgy ez az elmélet pontatlan nagyobb mennyiségű szerves, illetve karbonát tartalom mellett, mivel ezek abszorbálják a lézer fényt (FERRo and MIRABILE 2009).

A mintaterületről származó minták esetében a fent kifejtetteknek megfelelően a Fraunhofer elméletet használtuk a mérések során. A szemcseösszetételi vizsgálatra szánt mintákat először $90^{\circ} \mathrm{C}$-on kiszárítottuk, majd enyhén porítottuk. A méréseket Particle Sizer Analysette 22 MicroTec plus típusú, Fritsch gyártmányú műszerrel végeztük. A műszer mérési tartománya 0,08-2000 $\mu \mathrm{m}$, amely jól fedi a vizsgált üledékek szemcseméret-eloszlását. A mérés során a mintákat ultrahanggal homogenizáltuk ( $\mathrm{f}=36 \mathrm{kHz}, \mathrm{P}=60 \mathrm{~W}$ ) 3 percig. A mérés két lineárisan polarizált He-Ne lézerrel történt; zöld $(\lambda=532 \mathrm{~nm}, P=7 \mathrm{~mW})$ és infravörös $(\lambda=940 \mathrm{~nm}$, $\mathrm{P}=9 \mathrm{mw})$. A szemcseeloszlás 108 csatornára lebontva lett meghatározva (FRITSCH 2009). 

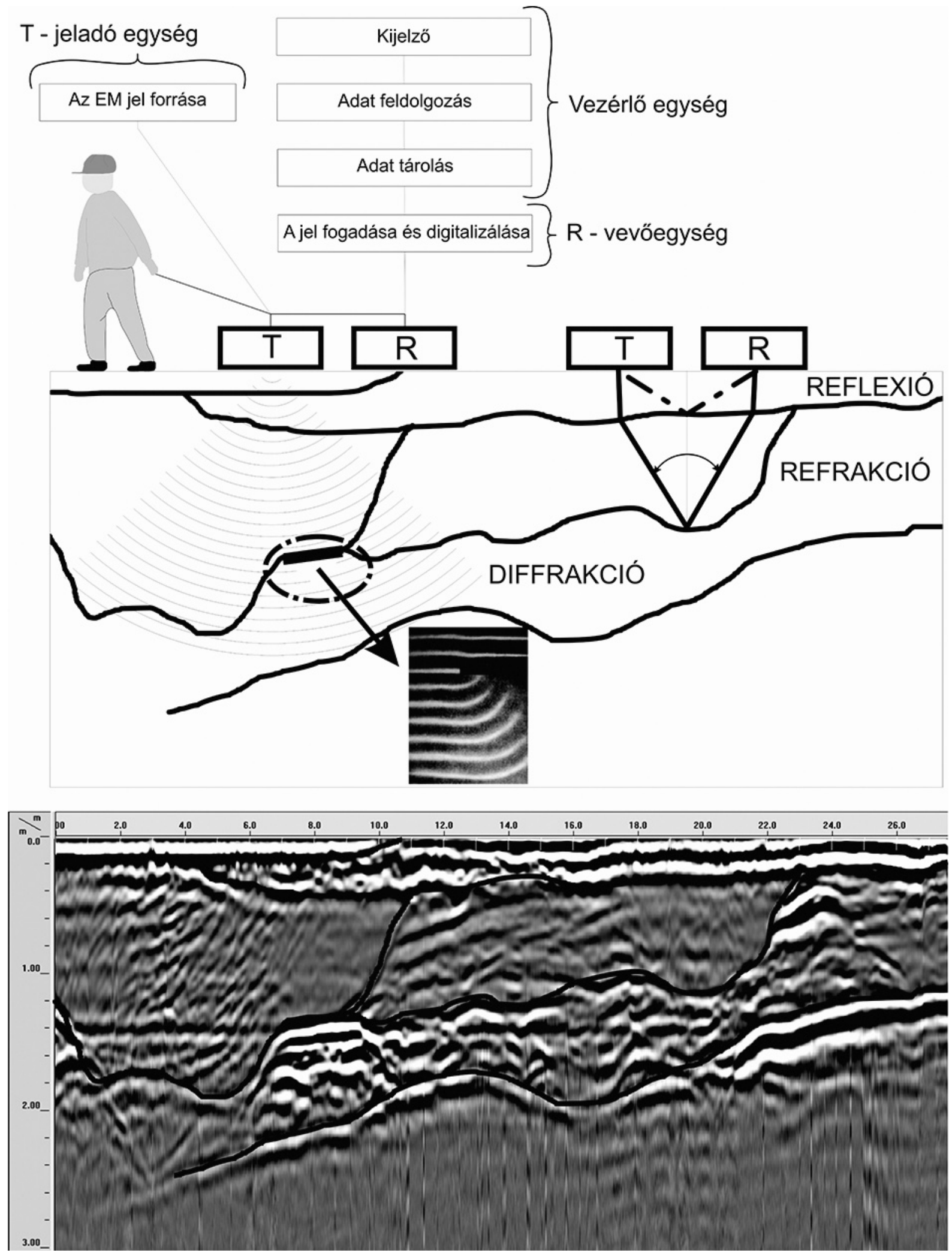

2. ábra. A georadaros (GPR) mérés semantikus ábrája (Katona et. al. 2013) 
A)

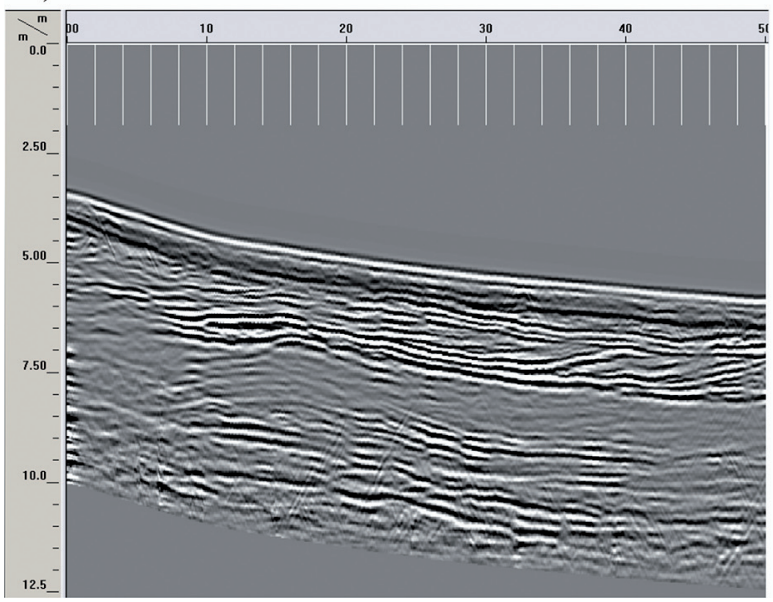

B)

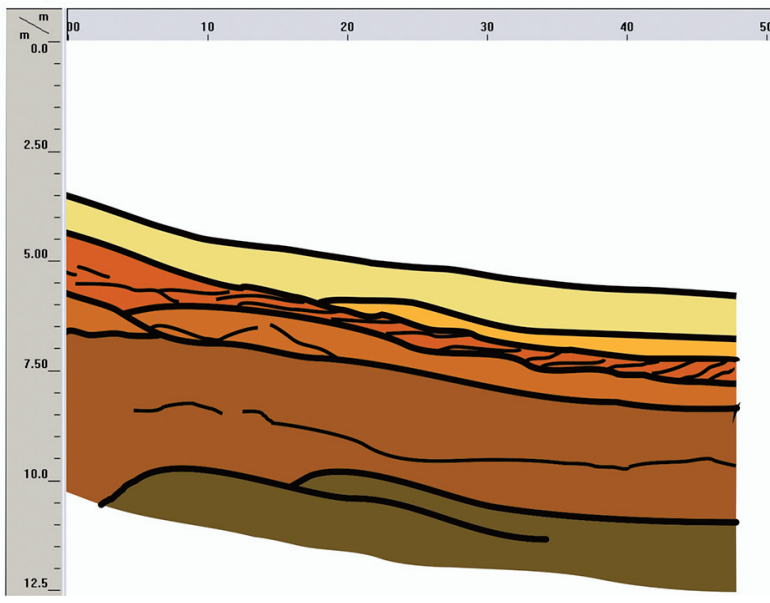

3. ábra. A felvett radarszelvény kiértékelése, példa az 590. szelvény egy szakaszán. A rétegszínek jelmagyarázatát lásd a 4. ábrán

A mérési eredmények alapján először meghatározásra került a gyűjtött minták szemcseméret eloszlása, majd a minták szemcseeloszlásának statisztikus paraméterei úgy, mint módusz, medián, szórás, ferdeség és csúcsosság, valamint közepes szemcseátmérő (D50) illetve D90, mindezekböl az ülepítő közeg energia viszonyaira lehetett következtetni (FoLK és WARD 1957, BÉRCZI és BALOGH 1992, BLOTT és PYE 2001).

Az osztályozásnál az összevont Udden és Wentworth-skálát használtuk (BLOTT és PYE 2012). A szelvények ábrázolása Tilia Graph programmal készült, melynek a segítségével klaszteranalízist is végeztünk, mely segítette a zónák és a szintek elkülönítését. A részletesebb kiértékeléshez Gradistat programban (BLOTT és PYE 2001), Folk és Ward (1957) módszere szerint meghatároztuk meg a $90 \%$-os kumulatív százalékhoz tartozó szemcseátmérőt, a $\mathrm{d}_{90}$-et, melynél a szemcsék $90 \%$-a kisebb, 10\%-a nagyobb átmérőjü.

\section{OSL kormeghatározás}

A bucka abszolút kora optikailag stimulált lumineszcens (OSL) mérésekkel került meghatározásra. Egy $210 \mathrm{~cm}$ és egy $280 \mathrm{~cm}$ mély fúrásból összesen öt mintát gyűjtöttünk. A háttérsugárzás laboratóriumi méréséhez az OSL minták alatti és feletti 10-20 cm-es fúrásanyagot tettük félre.

A laboratóriumi feltárás során először eltávolítottuk a minták mész- és szervesanyag-tartalmát, majd Napoliwolframát oldat segítségével $\left(2,62\right.$ illetve $\left.2,68 \mathrm{~g} / \mathrm{cm}^{3}\right)$ leválasztottuk a mérésekhez szükséges kvarc mennyiséget, amelyet azután 50 percen át $38 \%$-os hidrogénfluorid oldattal kezeltük, a szemcsék külső héjának eltávolítása céljából. A feltárás után a mérésekhez a 90-150 $\mu \mathrm{m}$ átmérőjű kvarcfrakciót használtuk fel, amelyeket acél korongokra vittünk fel, $6 \mathrm{~mm}$ átmérőjü maszkot alkalmazva. A tesztmérésekhez 40 , az egyenérték dózis meghatározásához 24 korongot készítettünk (SIPOs et al. 2009).

$A z$ egyenérték dózis méréséhez RIS $\varnothing$ TL/OSL DA15 típusú, 0,114 Gy/s dózisteljesítményü béta sugár- forrással ellátott müszert használtunk. A mintákat 470 nm-es kék fénnyel stimuláltunk, a detektáláshoz Hoya U-340 szürőt alkalmaztunk. A mérések során a széles körben alkalmazott egy-mintás regenerációs protokollt (SAR - Single Aliquot Regeneration), illetve az ahhoz kapcsolódó ellenőrző vizsgálatokat alkalmaztuk (WINTLE és MURRAY 2006). A tájékozódó méréseket követően $180-300^{\circ} \mathrm{C}$ között végeztük el az előmelegítési teszteket, $20^{\circ} \mathrm{C}$ lépésekben emelve a hőmérsékletet. $\mathrm{Az}$ előmelegítési tesztet megelőzően hosszú stimulációval eltávolítottuk a minták természetes lumineszcens jelét, és ismert nagyságú dózist sugároztuk be, így a tesztek során azt is meg tudtuk állapítani, hogy a vizsgált mintából összességében milyen pontossággal lehet az ismert dózist visszamérni (WINTLE és MuRRAY 2006).

Az egyenérték dózis meghatározásakor végül 230 $240{ }^{\circ} \mathrm{C}$-os előmelegítést alkalmaztunk a mintától függően. A kék fénnyel történő stimulálás $160{ }^{\circ} \mathrm{C}$-on történt. A kapott eredményeket Analyst 3.24, illetve MsExcel segítségével értékeltük. A természetes dózisteljesítményt meghatározó $U$, Th és $K$ koncentrációkat Canberra típusú félvezető Ge detektorral felszerelt nagy felbontású gamma spektrométerrel elemezték az ÁNTSZ Csongrád megyei Laboratóriumában. A koncentrációk alapján számított dózisteljesítmény eredményeket az anyag begyűjtésekor tapasztalt nedvességtartalommal (AITKEN 1998), valamint a kozmikus háttérsugárzással (PRESCOTT és HutTON 1994) korrigáltuk.

\section{Eredmények}

A vizsgálati terület komplex interpretálása érdekében, a már meglévő lézeres szemcseösszetétel és az OSL kormeghatározás eredményei, georadar szelvényezés alapján kiértékelt eredményekkel kerültek kibővítésre. A feldolgozott szelvényeken (3/A. ábra) a reflexió erössége alapján jól elkülöníthetőek voltak az üledékben található egységhatárok (3/B. ábra). Lehatárolásukat indokolja a különböző egységeken belüli eltérő 


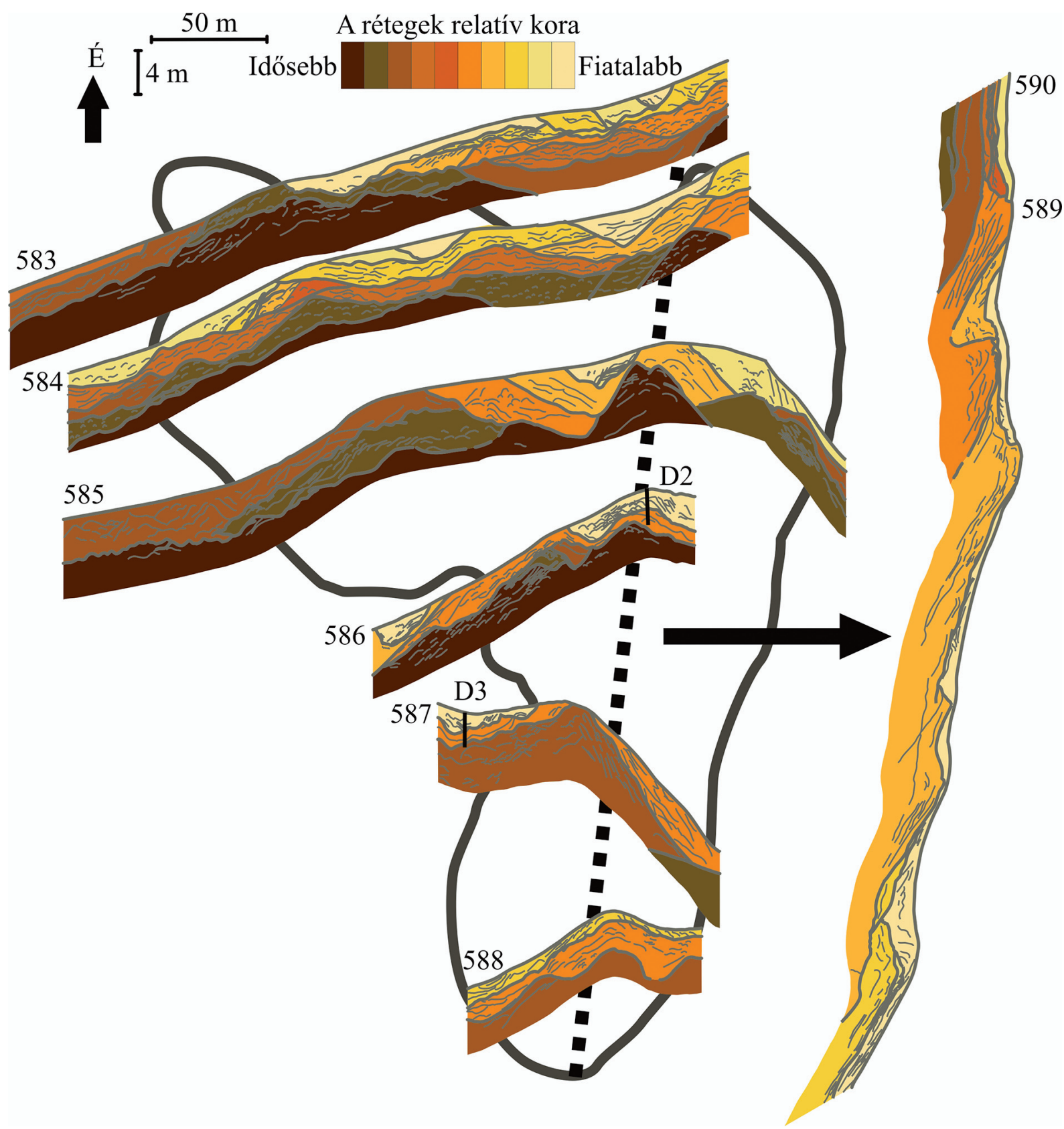

4. ábra. A vizsgált parabolabucka szerkezete a GPR szelvények alapján

rétegződés, melyet az egymást követő szélesemények eltérő jellege (szemcseösszetétel, homok mennyisége, szélsebesség, lokális akadályok szerepe) határoz meg. Ezek értelmezése utána, kölcsönös helyzetüket figyelembe véve összesen 10 radarfáciest különítettünk el. A rétegek településükből adódóan eltérő korúak lehetnek, azonban ez csak relatív kor (4. ábra), mely a topográfiai viszonyokból következtethető.

A parabolabucka formáját tekintve egyértelmű információval szolgál a hosszanti (589-590) szelvény (4. ábra), amelyen eredményeink szerint kimutatható a bucka északi részén a legidősebb radarfácies (sötétbarna színkód), és amely igazolja, hogy a feltöltődés - vándorlás iránya az uralkodó északi szeleknek megfelelően É-D volt. A keresztszelvényekben található legidősebb fáciest vizsgálva (4. ábra - 583-586 szelvény) megállapítható, hogy a bucka valószínüleg kevésbé kitöltött alakú, hajtűszerübb forma volt korábban. Ekkor a bucka legmagasabb, központi része az 585 szelvény keleti részén volt. A következő szél események eredménye képen először a forma nyugati szárnya épült, majd a vándorlásnak megfelelően a déli 


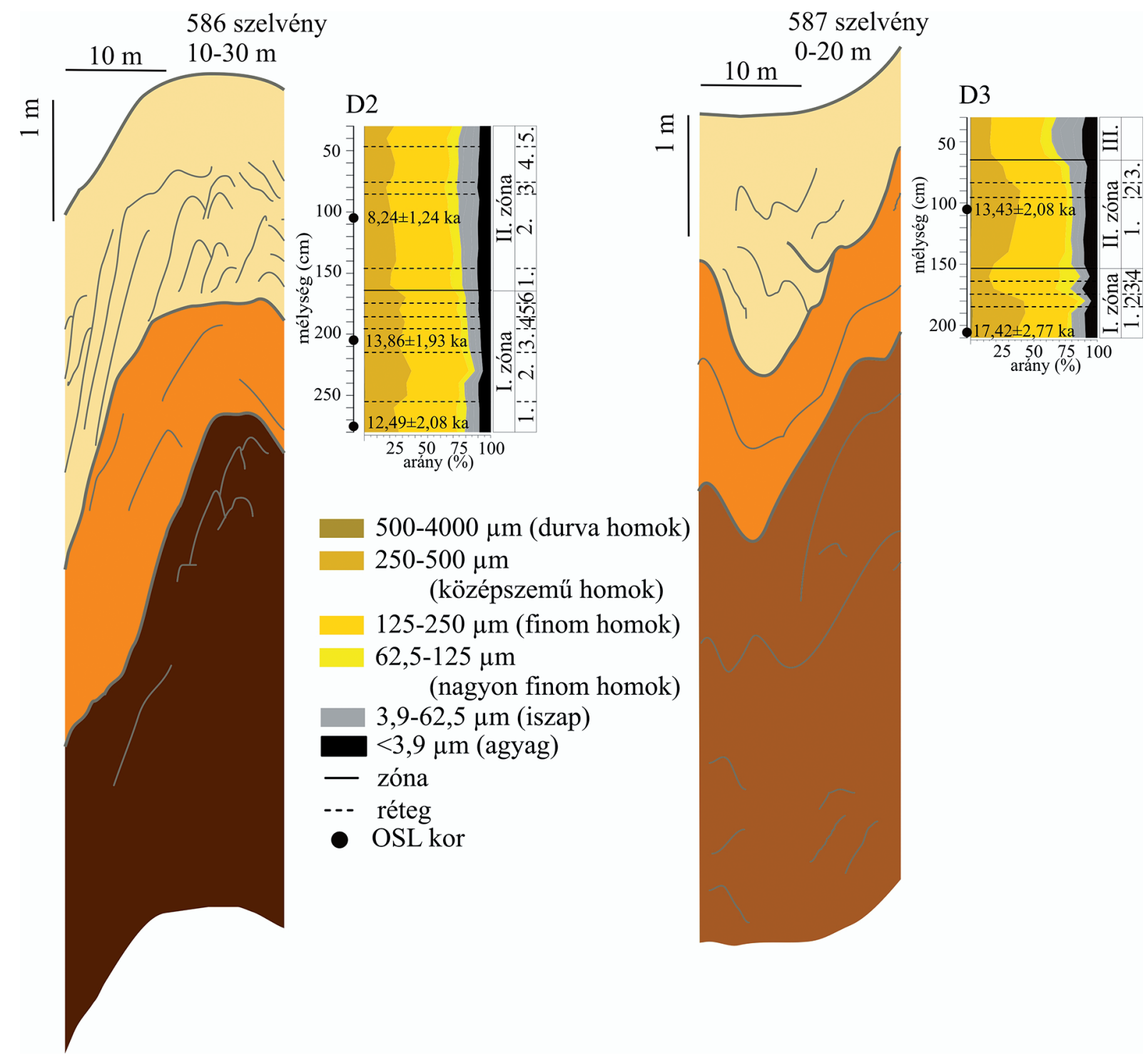

5. ábra. A georadar-felmérés eredményeinek összehasonlítása a szemcseösszetételi (Györgyövics et al. 2014) és az OSL mérések (Kiss et al. 2012) eredményeivel. A rétegszínek jelmagyarázatát lásd a 4. ábrán

részen is nagyobb mennyiségü homok halmozódott fel. Egyidőben a bucka két szára közötti központi mélyedés is kezdett feltöltődni. Az ebben az időben lerakódott rétegek kisebb mérete jelzi, hogy a feltötődés lassabb ütemben, szakaszosan (feltehetően kisebb széleseményekhez köthetően) történt. A fáciesek kölcsönös helyzete alapján pedig megfigyelhető, hogy a feltöltődés a nyugati szárny keleti oldalától indult. Öszszesen 5 nagyobb egység különíthető el, amelyeknek folyamatosan csökkent a vastagsága, tehát a lerakódó homok mennyiség is csökkent, vagyis stabilizálódott a felszín, az eolikus tevékenység fokozatosan visszaszorult. A felszínen elkülöníthető legfiatalabb fácies, feltehetően már egy ilyen korlátozott széleseményhez köthető, amely során a kisebb mélyedések kerültek kitöltésre. Azonban a fácies szerkezetében nem mu- tatható ki egyértelmű rétegződés, mely gyors lerakódásra, homoklepelszerü üledék kialakulására utal.

A bucka stabilizálódását követően, feltehetően a formafejlődés legutolsó szakaszai között utólagos szélmarás érte a bucka délnyugati részét. A forma alaprajza is jól mutatja az eróziót, illetve az 586 és az 587 szelvényen keleti felén mutatkozó hiátus, üledékhiány is erre utalhat. Azonban a georadar szelvényezéssel kimutató volt az is, hogy a későbbi szélesemény hatására a szélmarás során kialakult mélyedés részben feltöltődött eltérő rétegzettségű homokkal. Ez az üledék valószínüleg hasonló korú, mint a központi mélyedés feltöltődésének utolsó fázisában lerakódott anyag.

Összességében tehát elmondható, hogy a keresztszelvények konzekvensen követik egymást a relatív korú radarfáciesek egyértelműen végig követhetőek és 
a felszíni domborzat alapján interpretálható az eolikus mozgás iránya, a forma épülése, a lerakódások sorrendje. A georadar szelvényezés során figyelembe kell venni, hogy a 3D bucka esetében a keresztszelvények merőlegesen a szél irányára, ezáltal jól kimutatható a formán belüli rétegződés, az egységhatárok egyértelmüen elkülöníthetőek, míg a hosszanti szelvényesetében, mely párhuzamos a szél irányával ezek kisebb mértékben felismerhetőek. Ennek megfelelően a hoszszanti szelvényen lehatárolható radarfáciesek megfeleltethetőek a keresztszelvényben meghatározottakkal, de a relatív korbesorolásuk eltérő.

Azonban a hosszanti szelvényben a keresztszelvényeken bemutatott radarfáciesek ugyan felismerhetőek, de időbeli besorolásuk, azaz relatív koruk az elemzés alapján másnak adódik. Emiatt figyelembe kell venni, hogy a 3D bucka mérése közben a keresztszelvények merőlegesek a szél irányára, ezért általuk jól kimutatható a rétegződés, így az egységhatárok is egyértelműen elkülöníthetők, míg a hosszanti szelvény esetében, mely párhuzamos a széliránnyal, ezek kisebb mértékben felismerhetőek.

\section{Megvitatás}

A szemcseösszetétel alapján megállapított zónák párhuzamosíthatók a radarszelvények alapján megállapított fáciesekkel (5. ábra).

A D3 fúrást az 587. szelvény nyugati felében mélyítettük (4. ábra), ahol a radarszelvény alapján 3 fácies különíthető el. A D3 fúrás szemcseösszetételi eredményei alapján szintén elkülöníthető ez a 3 réteg ( 5 . ábra). A legalsó, I. zónában (210-155 cm) durva homok is található $(0,5-1,1 \%)$, a közepes szemű homok aránya fokozatosan csökken (41\%-ról 14\%-ra), miközben a középszemű homoké pedig 34\%-ról 56\%-ra nő $\left(\mathrm{d}_{90 a ́ t l}=336 \mu \mathrm{m}\right)$. A zónán belül két olyan szint fordul elő, amelyben a homokfrakció aránya magasabb. Ezt a két szintet a GPR felmérés is kimutatta, azonban az értékelés során már a második, fiatalabb zónához tartozónak soroltuk ezt a szintet. Feltehetően a reflexióban a legnagyobb különbség ott jelentkezett, ahol a szemcseméretbeli változás a legnagyobb (ennek megfelelően a fizikai jellemzői is mások), mely egyértelmüen a szemcseösszetételi diagrammon jelölt I. zóna 2. szintjében figyelhető meg. A legalsó rétegből

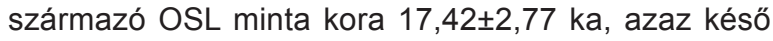
pleisztocén homokmozgásra utal, melynek során durva


$A$ radarszelvényben eltérően értelmezett, finomabb réteg, a szemcseösszetétel szerinti 1/2-4 szintek feltehetően a hideg időszakok közötti interstadiálisokban (Bölling és/vagy Alleröd) enyhén talajosodott szintek lehetnek.

A D2 fúrás (az 586. szelvény keleti végében, 4. ábra) mélyítésekor nem értük el a radarszelvény által kimutatott legalsó, zónát, ezért annak szemcseösszetételéről és koráról csak a GPR mérések alapján meghatározott rétegek segítségével következtethetünk. A bucka teljes szerkezetét tekintve valószínűsíthető, hogy a legidősebb rétegek közé tartozik, tehát minimum késő pleisztocén korú, vagy ennél idősebb.

A 587. és az 586. szelvények középső radarfáciese mindkét fúrásban jól elemzett és datált (5. ábra). A D3 fúrásban ez a második zónának felel meg, melynek szemcseösszetétele viszonylag egységes $\left(\mathrm{d}_{90 a ́ t}=335 \mu \mathrm{m}\right)$, egy középszemü homokban gazdagabb (38\%) réteg (85-95 $\mathrm{cm}$ ) osztja három szintre. A D2 fúrásban ez az I. zóna, melyben a középszemű homok aránya (25-36\%) és a $d_{90}$


mosítható zónájával. A két fácies az OSL korok alapján is azonos időszakban rakódott le, hiszen mindhárom megmért minta kora $(13,43 \pm 2,08$ ka,valamint $12,49 \pm 3,68$ ka és $13,86 \pm 1,93 \mathrm{ka})$ a késő-glaciálisra tehető.

A legfelső réteg szemcseösszetétele is hasonló a két fúrásban. Azaz megnőtt az iszap- és anyagtartaIom, mely a D3 fúrás III. zónájában a fúrás topográfiai helyzete miatt $32-36 \%\left(\mathrm{~d}_{90 a ́ t l}=280 \mu \mathrm{m}\right)$, míg a kiemelt helyzetű D2 fúrásban a felső rétegben a középszemű homok aránya még mindig $17-25 \%\left(\mathrm{~d}_{90 a ́ t l}=302 \mu \mathrm{m}\right)$. A fácies abszolút kora csak a D2 fúrásban került meghatározásra, amely boreális homokmozgást jelez $(8,24 \pm 1,24 \mathrm{ka})$. A szemcseösszetételi adatok alapján a réteg viszonylag egységes, a pulzusokban lerakódó homok rétegei az 586-os szelvény elemzése és az eredményekkel párhuzamosítható D2 fúrásban kimutatott szintek jól jellemzik. A D3 fúrás legfelső zónájában és ennek megfelelően 587 szelvény felső fáciesében nem kimutathatók ezek a laminák. Vagyis, ha feltételezzük, hogy szemcseösszetételbeli hasonlóságaik alapján a rétegek egykorúak, a boreálisban rakódtak le, akkor feltételezhető, hogy a mélyedés gyorsabban töltődött fel, míg a kiemelt helyzetben lévő helyen fokozatosan rakódott le a homok, az eolikus formák vándorlásánál leírt felhalmozódás-lecsúszás révén egy újabb réteg alakult a már korábban stabilizálódott buckatetőn.

\section{Konklúzió}

A korábban rendelkezésre álló OSL adatok és szemcseösszetételi eredmények alapján a formát egy egységes buckának tekintettük, mely 3 fázisban épült. Ezzel szemben a georadaros mérések alapján elmondható, hogy a bucka épülésének minimum 10 fázisát lehet megkülönböztetni. Ugyan a fázisok egymás közötti viszonya nem mindenhol egyértelmű, azonban ezeknek az ismeretében már célravezetőbben tervezhető a laboratóriumi mérésre szánt, így szükségszerűen pontszerű fúrások, mintavételezések helye. Például a radarszelvények ismeretében a D2 fúrásból a harmadik, vagyis legalsó mintát min. 1 méterrel mélyebbről célszerü begyűjteni, hiszen így az alsó, idősebb réteg (zóna) kora is pontosan megadható. Továbbá a radarfáciesek ismeretében elkerülhető, hogy a radarszelvények és a szemcseösszetételi eredmények alapján is egységes zónából két minta kerüljön drága és időigényes kormeghatározó laboratóriumba (pl. D2 fúrás, I. zóna).

Ugyanakkor a radarfáciesek mindegyike nem különíthető el, nem található meg a bucka teljes területén, egyes fázisok csak lokálisan mutathatóak ki. Szemiarid 
környezetben az eolikus felszínfejlődést nemcsak a szélirány, a szélerősség és a homokutánpótlás mennyisége határozza meg, hanem számos a sivatagihoz képest változékonyabb klímából adódó (csapadék menynyisége, eloszlása, hőmérséklet évszakos és hosszabb ciklusú változása, stb.) és helyi jelentőségü tényező (vegetáció magassága, sürüsége, változása, szerteágazó emberi hatások) is. Ezért a félig kötött homokterületeken a buckák gyakran csak lokálisan épülnek, módosulnak, átalakulnak, felszabdalódnak. Jóllehet, nem minden radarfácies korának és szemcseösszetételének meghatározására nyílik lehetőség, de a módszerek öszszekapcsolásával, komplex használatával egy átfogó felszínfejlődés leírása adható meg.

A jelen tanulmányban vizsgált bucka fejlődéstörténetének pontosabb interpretációjához, a GPR felmérés elvégzése és a radarszelvények kiértékelése után többek között javasolható, az 585. szelvény keleti végénél és az 588. szelvény középső részéről történő mintavétel, melyek kormeghatározása részletesebb adatokkal szolgálna.

\section{Köszönetnyilvánítás}

Györgyövics Katalin publikációt megalapozó kutatása a TÁMOP 4.2.4.A/2-11-1-2012-0001 azonosító számú Nemzeti Kiválóság Program - Hazai hallgatói, illetve kutatói személyi támogatást biztosító rendszer kidolgozása és működtetése országos program című kiemelt projekt keretében zajlott. A projekt az Európai Unió támogatásával, az Európai Szociális Alap társfinanszírozásával valósul meg. Továbbá a műszerek használatáért köszönet a Szegedi Tudományegyetem Természeti Földrajzi és Geoinformatikai Tanszékének.

\section{Irodalom}

ÁdÁm L., MARosı S. és SzILÁRD J. 1981: A Dunántúli-dombság: DélDunántúl. - Akadémiai Kiadó, Budapest. 704

AITKEN, M.J. 1998: An introduction to optical dating. Oxford University Press. Oxford. 266.

BÉRCZI I. és BALOGH K. 1991: A törmelékes üledékes kőzetek szövete. In: Balogh K. (ed.). Szedimentológia I. kötet, Akadémiai Kiadó, Budapest, 454-499.

BLOTT, S.J. \& PYE, K. 2001: GRADISTAT: a grain size distribution and statistics package for the analysis of unconsolidated sediments. - Earth Surface Processes and Landforms 26(11): 1237-1248.

BLOTT S. J. \& PYE K. 2012: Particle size scales and classification of sediment types based on particle size distributions: Review and recommended procedures. - Sedimentology 59: 2071-2096.

CAsa A., Pinto V. \& Rivero L., 2000: Fundamentals of ground penetrating radar in environmental and engeneering applications. - Annali di geophysica 43(6): 1091-1103.

CHOLNOKY J. é.n.: Somogy vármegye természeti viszonyai. Magyarország vármegyéi és városai. Somogy vármegye. Budapest

Di Stefano C., Ferro V. \& Mirabile, S. 2010: Comparison between grain size analyses using laser diffraction and sedimentation methods. - Biosystems Engineering 106: 205-215

FERRO V. \& MIRABILE S. 2009: Comparing particle size disturbation analysis by sedimentation and laser diffraction method. - Journal of Agricultural Engineering 2: 35-43.

FRITSCH 2006. Laser Particle Sizer - Static laser Scattering, Fritsch Analysette 22. Fritsch $\mathrm{GmbH}$, Manufacturers of Laboratory Instruments, Germany (http://www.fritschsizing.com/uploads/ tx_downloads/e_ANALYSETTE_22.pdf)

FOLK, R. L., WARD \& W.C. 1957: Brazos river bar: a study in the significance of grain size parameters. - Journal of Sedimentary Petrology 27 (1): 3-26.

GYÖRGYÖVICS, K. \& KISS T. 2013: Dune hierarchy and morphometric classes of the parabolic sand dune association of Inner Somogy, Hungary. - Studia Geomorphologica Carpatho-Balcanica 47(1): 31-48.

GYÖRGYÖVICS, K., KISS, T. \& SIPOS, GY. 2014: Grain size distribution of stabilised aeolian dune sediments in Inner Somogy, Hungary. - Journal of Environmental Geography 7(3-4): 49-58.

Loizeau J. L., Arbouille D., Santiago S. \& Vernet J. P. 1994: Evaluation of wide range laser diffraction grain size analyser for use with sediments. - Sedimentology 41: 353-361.
JOL H. M., 2009: Ground penetrating radar theory and applications, Elsevier Science Radarweg 29, PO Box 211, 1000 AE Amsterdam, The Netherlands, printed in Slovenia

Katona O., Sipos Gy., Fiala K., Rakonczal J. és Mezősı G. 2013: A georadar müködése és felhasználási területei, különös tekintettel a hidrológiai kutatásokra I. rész: müködési elv, fontosabb alkalmazások. - Hidrológiai Közlöny 93(4): 55-60.

KISs T., GYÖRgYövics K. és SıPos GY. 2012: Homokformák morfológiai tulajdonságainak és korának vizsgálata Belsö-Somogy területén. - Földrajzi Közlemények 136(4): 361-375

Kun Á., Katona O., Sipos Gy. és Barta K. 2013: Comparison of Pipette and Laser Diffraction Methods in Determining the Granulometric Content of Fluvial Sediment Samples. - Journal of Environmental Geography 6(3-4): 49-54.

LóKı J. 1981: Belső-Somogy futóhomok területeinek kialakulása és formái. - Közlemények a Debreceni Kossuth Lajos Tudományegyetem Földrajzi Intézetéből 139: 81-107.

MAROSı S. 1967: Kovárványrétegek és periglaciális jelenségek összefüggésének kérdései a belsö-somogyi futóhomokban. - Földrajzi Értesítő 15: 27-40.

MARosı S. 1970: Belső-Somogy kialakulása és felszínalaktana. Akadémiai Kiadó. Budapest

PÉcsı M. 1962: A magyarországi pleisztocénkori lejtős üledékek és kialakulásuk. - Földrajzi Értesítő 11: 19-39.

Prescott, J. R. \& Hutton, J. T. 1994: Cosmic ray contributions to dose rates for luminescence and ESR dating: large depths and longterm time variations. - Radiation Measurements 23: 497-500.

SIPOS GY., KISS, T. és NYÁRI, D. 2009: Kormeghatározás optikai lumineszcenciával: homokmozgások vizsgálata a történelmi időkben Csengele területén. In: Az elmúlt 500 év környezeti eseményei történeti és természettudományi források tükrében. Hatken Kiadó. Budapest 409-420.

XU R. \& DI GUIDA O. A. 2003: Comparison of sizing small particles using different technologies. - Powder Technology 132: 145-153.

WintLe, A. G. \& MURRAY, A. S. 2006: A review of quartz optically stimulated luminescence characteristics and their relevance in single-aliquot regeneration dating protocols. - Radiation Measurements 41: 369-391. 